\title{
THE ROLE AND IMPACT OF TRANSPORT SERVICES DURING WORLD YOUTH DAY 2016
}

\author{
EWA GRABIŃSKA \\ Jagiellonian University in Cracow, POLAND \\ e-mail: e.grabinska@uj.edu.pl
}

RECEIVED
ACCEPTED
JEL
CLASSIFICATION

KEYWORDS

ABSTRACT

\author{
14 July 2017 \\ 15 December 2017 \\ Z32, R40, L90
}

Tourism and development, Transportation Economics, Transportation and Utilities

Many elements contribute to the shaping of a tourist product. One of them is transport services. It does not only offer the possibility to reach a certain significant destination, but also to move around the target area. The topic of transport services supporting huge mass events, such as World Youth Days, is especially interesting. The essay presented the results of the research as well as provided an analysis and estimation to what extent expectations were met and the needs related to transport services during World Youth Day hosted by the city of Cracow were satisfied. The main aspect for the study was the idiosyncrasy of the transport service market, further on the issue of competitiveness between particular branches of transport was covered. The questions of the role and significance of transport services were raised, paying special attention to transport availability of a certain destination on the example of Cracow, based on the data collected during Youth Day held in 2016 as well as the Research on Tourist Movement within the City of Cracow in recent years.

\section{Introduction}

In many places in the world, tourism can only develop when access to a certain destination is guaranteed. Nowadays, it is not only important that a certain connection exists, but that a traveller may choose the most convenient and comfortable means of transport, as well as be granted a reliable mobility option at the target destination, which contributes to what decisions they will make. In particular, it is essential to guarantee and secure 
the transport services during huge mass events, which World Youth Days are. It must be noted that it is not only a religious and spiritual event, but it also poses a huge effort from organisational and logistic point of view, especially in the aspect of servicing and communication solutions. Between $23^{\text {rd }}$ July and $1^{\text {st }}$ August 2016, the city of Cracow hosted XXXI World Youth Day (further referred to as WYD 2016), which was the largest mass event ever organised in our country - almost 3 million pilgrims from 187 countries participated in it. WYD 2016 required numerous organisational actions to be taken, not only to facilitate the arrival of the pilgrims from many parts of the world, but also to provide transportation within the city borders and its surroundings as part of the meetings and celebrations held. In this evaluation, we undertook the issues on the significance and role of the transport service on the example of the case study of WYD 2016, yet paying also attention to the data obtained from the annual Research on Tourist Movement within the City of Cracow. It is worth mentioning that the transportation issues should be viewed from many perspectives due to the fact that preparation and organisation of such events - specific international mass events - are not an easy task to undertake. In particular, what is essential is the questions concerning communication solutions used, guarantee of safety and security, quality requirements, as well as tourists' patterns and preferences when choosing means of transport to reach such destinations.

\section{The nature of transport service and its impact on tourist product}

The existence and availability of reliable transportation is a key factor to facilitate correct operation of a tourist system. The development of tourism is closely related to the innovations in transport services occurring right in front of our eyes. The development of transport services led to the reduction of costs and time of the transport services, which, as a result, changed tourism from an elitist phenomenon to a common one (Sawicki, 2012, p. 1957). In the $19^{\text {th }}$ century, the railway revolution made it possible for T. Cook to offer the first type of tourist packages for a greater number of people. Similarly, the appearance of wide-bodied passenger aircraft in the 1960's, so called jumbo jets, contributed to the mass spread of international tourism (Gierczak, 2011, p. 278). It is accepted that a tourist service cannot be realised without providing transport service since transportation is a key element facilitating the connection between the place of origin and the destination. The transport service is not only an important, but also necessary component of tourist product because without it the tourist product cannot be consumed (Khadaroo, Seetanah, 2007, p. 1023). Among tourist products we can distinguish a product in the strict sense, and a broader one - it is a complex concept and it consists of many various elements: both tangible and intangible assets, including transport services. We recognise the nature of the product, real product and extended product - transport services are in the two latter groups. In the literature on the subject we can also find the concept of simple products, which includes a particular tourist service, e.g. hotel, boarding, guiding or just transport (Stec, 2015, pp. 233-248).

The concept and role of transport service is closely related to transport availability (Kwarciński, 2012, pp. 169-173), which in economic aspects reflects generalised monetary and non-monetary costs (time, money, effort, discomfort, risk) necessary to reach a particular place or function. Transport availability plays a key role for a given destination, especially for its correct development from the perspective of tourist economy. Moving around a target destination is equally essential; transport services may also play a recreational and entertaining role, and some means of transport are a tourist attraction in themselves, for example a narrow-gauge railway ride or a ferry (Gosik, Zimon, 2014, p. 42). Transport service does not only decide on economic attractiveness of the region, but is also an essential component for development of the tourist product, contributing to its overall rating. It means that transport service is one of the key services conditioning tourist movement, first of all to provide connection to and 
within a tourist destination, but also essential to consume a tourist product (cf. Turek, 2009, pp. 27-40; Panasiuk, 2008, pp. 70-108).

We can distinguish the following four main transport branches: road (car/coach), railway, waterways and aviation. Detailed comparative analyses of their pros and cons prove that air transport guarantees relatively the shortest time of travel, railway transport provides a high level of safety, waterways transport is useful for sightseeing and recreational purposes, road transport, on the other hand, is the most convenient because it allows to directly reach a destination, a tourist attraction or accommodation (cf. Bednarczyk, Grabińska, pp. 44-46; Mammadov, 2012, pp. 381-386). Prospective tourists also show individual preferences, which significantly influences their choice of a particular means of transport (cf. Wilkońska, Rotter-Jarzębińska, 2013, p. 175). The decision to choose a means of transport is made based upon various factors such as: possibility to access a destination directly; price (funds for travel); travel time (time limitations, speed); quality; comfort, convenience or additional services; distance to destination (short/long-hauled or domestic/international/intercontinental; the carrier's reliability (infallibility, transport capacity), restrictions on luggage, electronic system of booking, and an increasingly important factor - safety (cf. Westlake, Robbins, 2005, p. 463). Transport services have to be viewed from the perspective of many factors which significantly determine the decision made by a prospective passenger concerning their choice of a convenient means of transport, resigning at the same time from alternative forms or even changing tourist destination. Since a prospective passenger makes that choice, particular branches of transport compete. The process is referred to as substitutive competitiveness. The basis for this process is the phenomenon of substitutability in transportation, which results from economical homogeneousness of transport services and facilitates replacement of one with any other (cf. Bednarczyk, Grabińska, pp. 55-66). The competition relies mainly on competing for a prospective customer, propagating and easing access to the services offered, providing services which are increasingly cheaper, but at the same time of higher quality, because the demand for transport services influences substitutability of those services, connected by high cross-price elasticity of demand. Current market requirements force carriers to provide high security measures and quality on every stage of travel, and contemporary travellers expect a broad and personalised offer of transportation services. The notion concerning the delivery of transportation services during important events is a complex problem not only in economic, technical and organisational aspect, but also due to other challenges and needs.

\section{World Youth Day 2016 from the perspective of transport services}

World Youth Day made history for all Christians over the world. This special event of religious nature has been taking place regularly every 2-3 years in various countries since 1984, each time gathering a huge swarm of young people (Singleton, 2009, pp. 1-12). With time, WYD developed its program up to a couple of days, when

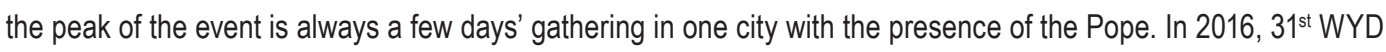
took place, and the main host of the edition was the City of Cracow. Prior to that, in 1991 Poland organised WYD in Częstochowa and is in this way - beside Italy and Spain - one of the three countries which hosted pilgrims to this religious event twice. The events usually attract from a few thousands up to a few millions of pilgrims. World Youth Days have always attracted huge masses of participants from other parts of the world, with the peak number (estimated at 5 million) of pilgrims reported in Manila in 1995, followed by Rio de Janeiro with its 3.5 million visitors in 2015. The high level of internationalisation observed from the beginning has ranged from 40 countries to 200 . Nowadays, representatives from 160-170 countries on average participate in the events. 
The latest WYD saw almost 3 million pilgrims during the whole period, facing the challenge of providing transportation and communication for about 1.5 million people at its culminating moments like the Holy Mass in Brzegi. Through the website, altogether 356,294 pilgrims from 187 countries registered for WYD 2016, with the most from Poland $(78,443)$ and Italy $(63,496)$. From France 32,979 people confirmed their arrival, from Spain 30,592; the USA and the remaining North America - 23,563; Germany - 11,653; Brazil - 9,777; Czechia - 5,945; Slovakia $-5,666$ and Portugal $-5,454$. The remaining participants were not registered, and this group primarily consisted of the Polish youth. Among foreigners who came to WYD in Cracow, the top groups were from France (16.76\%) and Italy (15.68\%), significantly surpassing Germans (8.16\%), Spaniards (6.36\%) or Portuguese (4.99\%), and visitors from beyond the pond (the USA) accounted for about 7.08\% participants (Research on WYD, 2016). The organisation of WYD 2016 was connected with numerous actions aimed at not only enabling a huge number of pilgrims from all over the world to come to Cracow, but providing for their mobility within the city and its surroundings to access the events, meetings and celebrations. It has to be noted that the organisers, predicting huge numbers of tourists (cf. Szarata, Drabicki, 2016, pp. 522-530), decided to heavily rely on public transportation according to the postulates and guidelines concerning the benefits from the prioritising of public transport services (cf. Gutiereez, Miravet, 2016, p. 3). Considering the question of transport availability, it has to initially be noted that Cracow lies on a very important communication route and is connected with many cities and regions both by motorways (A4) and express roads $(\mathrm{S} 7,94)$, or railway connections (there are two important stations: Central Station and Kraków Płaszów). It is significant that Cracow is conveniently located close to the second largest airport in Poland, KrakówBalice. The existence and smooth operation of railway stations and airports, or road corridors, has a huge impact on Cracow's accessibility (cf. Jaremen, Nawrocka, 2012, pp. 401-414; Seweryn, 2007, pp. 25-44).

Due to the analysis, motifs and preferences of tourists heading for WYD in Cracow in 2016 not only based on the data from the research on WYD 2016, but also from the perspective and in relation to the annual research on tourist movement within the City of Cracow. In the above mentioned analyses, the means of transport mentioned by respondents were aggregated. In the rows of Table 1 options of variants mentioned by respondents were places, and in columns the names of aggregates are listed. As it may be noticed, in the case of private cars and trains no equivalents were needed. The planes of budget airlines, regular airlines and charters were aggregated in the

Table 1. The rule of aggregation of transportation categories mentioned by respondents

\begin{tabular}{|c|c|c|c|c|c|c|c|}
\hline \multirow{2}{*}{$\begin{array}{l}\text { Means of transport } \\
\text { mentioned }\end{array}$} & \multicolumn{7}{|c|}{ Aggregator } \\
\hline & plane & car & bus & train & (empty) & other & total \\
\hline Car & & 8,698 & & & & & 8,698 \\
\hline Budget airline plane & 5,735 & & & & & & 5,735 \\
\hline Train & & & & 5,326 & & & 5,326 \\
\hline Coach & & & 4,286 & & & & 4,286 \\
\hline Regular line plane & 4,231 & & & & & & 4,231 \\
\hline Regular line coach & & & 2,177 & & & & 2,177 \\
\hline Mini-bus & & & 1,571 & & & & 1,571 \\
\hline Charter plane & 444 & & & & & & 444 \\
\hline (Empty) & 1 & & & & 243 & & 244 \\
\hline Other & 1 & & 5 & & & 197 & 203 \\
\hline Total & 10,412 & 8,698 & 8,039 & 5,326 & 243 & 197 & 32,920 \\
\hline
\end{tabular}

Source: own research based on the Research on WYD 2016 and the Research on Tourist Movement within the City of Cracow 2008-2016. 
analyses under one label - 'planes'. Besides, the category 'bus' includes charter coaches, regular line coaches and mini-buses. Due to the low number of responses concerning 'others' it was omitted in the analyses, as well as the cases of no answer. The results of the aggregation were collected in Table 2.

Table 2. Results of aggregation of means of transport in the categories planes and buses

\begin{tabular}{lrc}
\hline \multicolumn{1}{c}{ Aggregation of means of transport } & $\mathrm{n}$ & $\%$ \\
\hline Plane & 10,410 & 56 \\
$\quad$ budget airline plane & 5,735 & 31 \\
regular line plane & 4,231 & 23 \\
$\quad$ charter plane & 444 & 2 \\
\hline Bus & 8,034 & 44 \\
coach & 4,286 & 23 \\
regular line coach & 2,177 & 12 \\
$\quad$ mini-bus & 1,571 & 9 \\
\hline Total amount & 18,444 & 100
\end{tabular}

Source: own research based on the Research on WYD 2016 and the Research on Tourist Movement within the City of Cracow 2008-2016.

The percentage shares of the means of transport used by tourists coming to Cracow were exemplified in graphs (1-4). The first graph presents all types of transportation for all the years 2008-2016, while the other two graphs refer to the last three years 2014-2016. One of those graphs presents the structure of the types of transportation over the years, and the other to the contrary - the changes occurring in particular years within each category of transportation.

Summing up the up-to-date analyses, it has to be stated that the preferences of tourists arriving at WYD 2016 were slightly different from the preferences of tourists obtained in annual reports. The organisers of WYD 2016 decided to prioritise public transport, and as the research and analyses show, pilgrims heading for WYD 2016 in Cracow mainly used various services of the public transport, especially road public transport (coaches were used by $48 \%$ respondents from Poland and abroad who came to WYD, and only $8 \%$ of pilgrims used private cars). Another means of transportation favoured by pilgrims was the train (a third of participants). The trains which ran during WYD (2,596 regular lines and 398 special trains ordered by dioceses) carried $1.1 \mathrm{~m}$ passengers altogether. The coordinator of railway transport for WYD was PKP Polish Railways, taking responsibility for the infrastructure and the timetable. 10,000 railway workers altogether were responsible for servicing transportation for WYD, including 200 informative staff and 100 mobile ticket cashiers at the railway stations. Planes were used by $16 \%$ of all participants of WYD. A dominant role in the air transport was played by Cracow's airport - John Paul II International Airport Kraków-Balice. Between $19^{\text {th }}$ July and $9^{\text {th }}$ August 2016, Cracow airport served about 40,000 passengers and ran 208 extra air traffic operations. On 25 and $26^{\text {th }}$ July, there were 16 flights outside the regular timetable. The record number of passengers came to Cracow on Sunday $24^{\text {th }}$ July and the next day $-10,312$ and 10,453 respectively; though pilgrims arriving in Poland also used other airports, e.g. Warsaw Chopin Airport, Katowice International Airport, Rzeszów-Jasionka Airport. Air transport was chosen by pilgrims from remote locations and older people (over 60yo) due to convenience. Such a spread of means of transport used resulted from the fact that participants of WYD were arriving in Cracow in great numbers within a short time, which is why planes and cars were used less frequently than collective transportation (buses, trains). 


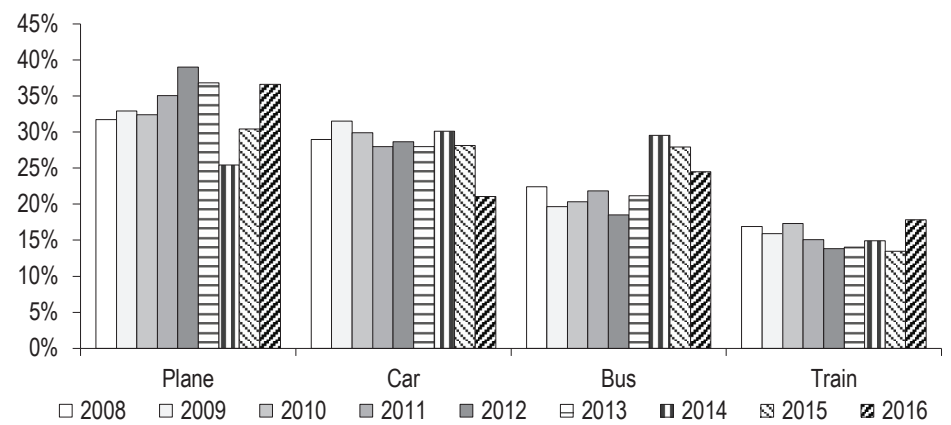

Figure 1. The percentage share of the means of transport used by tourists visiting Cracow in the years 2008-2016

Source: own research based on the Research on WYD 2016 and the Research on Tourist Movement within the City of Cracow 2008-2016.

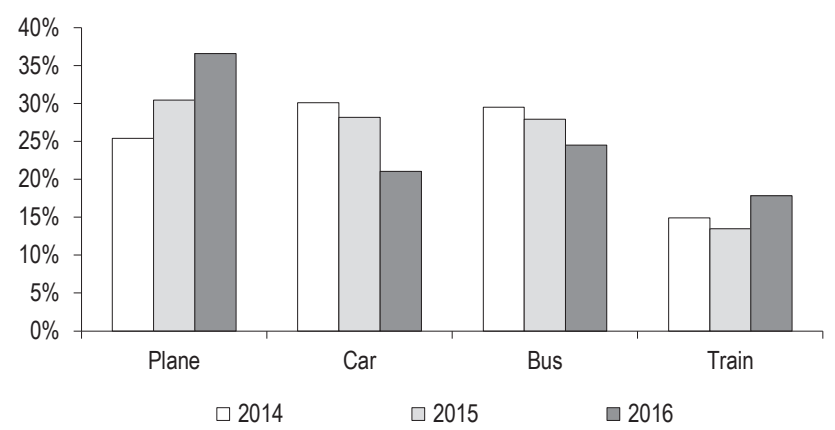

Figure 2. The percentage share of the means of transport used by tourists visiting Cracow in the years 2014-2016

Source: own research based on the Research on WYD 2016 and the Research on Tourist Movement within the City of Cracow 2008-2016.

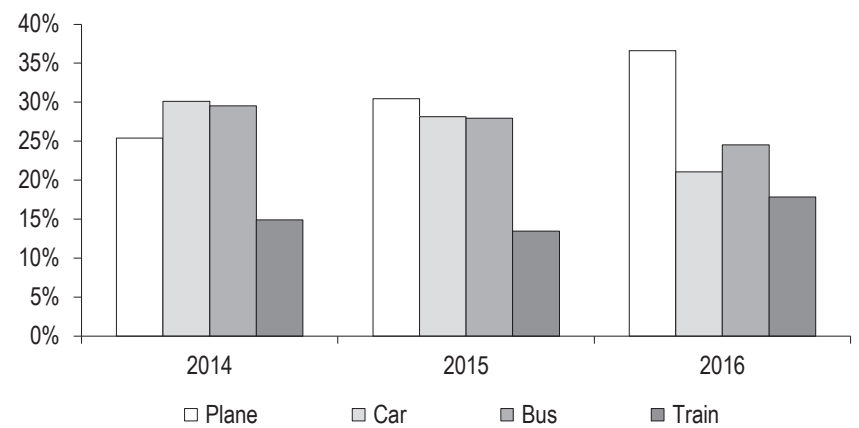

Figure 3. The percentage share of the means of transport used by tourists visiting Cracow in the years 2014-2016

Source: own research based on the Research on WYD 2016 and the Research on Tourist Movement within the City of Cracow 2008-2016. 


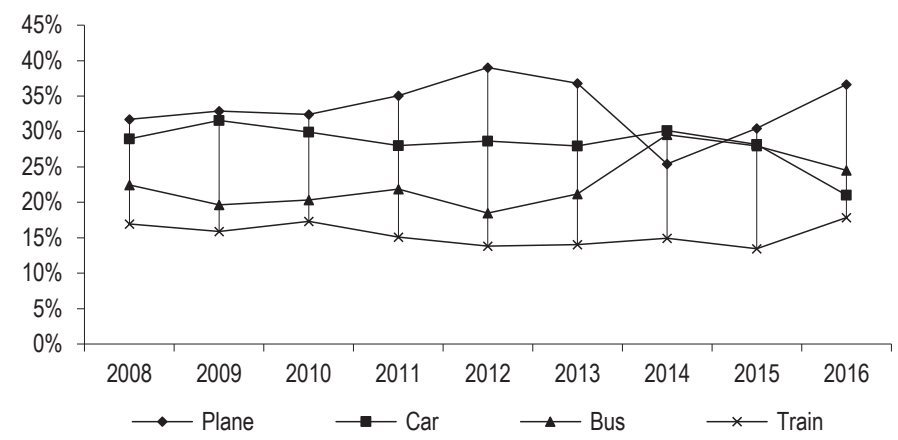

Figurle 4. The percentage share of the means of transport used by tourists visiting Cracow in the years 2008-2016

Source: own research based on the Research on WYD 2016 and the Research on Tourist Movement within the City of Cracow 2008-2016.

One of the vital challenges is the transportation solution in Cracow that was used in the context of the organisation and course of the events of WYD 2016. Due to the special attention paid to the security during WYD 2016, special commands were set up at transport stations, e.g. Railway Emergency Command. During the events in Cracow, municipal public transportation played a significant role. MPK (Municipal Transport Company) in Cracow had 288 trams and 623 buses at their disposal. Some areas were completely excluded from traffic and available only to pedestrians, emergency vehicles and technical support. Special passes were to make public transport attractive, and all Pilgrim's Packages supported free rides on the public transportation, including agglomeration and railway. It must be remembered that it was not only passenger transportation that was a real challenge, but also distribution and checking tickets, proper marking and information for passengers within the venues serving as stations, or marking on the communication routes. For example, 70 volunteers from Poland, Slovakia, Lithuania, Ukraine, Canada, Germany, Italy, Romania, Malaysia, Croatia and Vietnam worked at Cracow airport. The staff of information points and $24 \mathrm{~h}$ Call Centre on the airport premises helped over 19,000 persons (from $23^{\text {rd }}$ July to $3^{\text {rd }}$ August). Also passengers of railways were provided service and help at the highest level. That is why it was decided that special buffer zones be created and mobile cashiers employed. The attitude of the transportation servicemen was also important - their kindness, hospitality, helpfulness towards the needy as well as professional approach to their duties.

\section{Conclusion}

The notion concerning the delivery of transportation services during important events are a complex problem not only in economic, technical and organisational aspect, but also due to other challenges and needs. It is essential to set goals and needs within the provided transportation services, especially identifying and estimating transportation demand, preferences for the choice of a means of transportation, setting out the rules for traffic organisation or organisation of the information system. WYD is a form of religious tourism, but it is not only the motivation or religiousness of the participants that have an influence on the perception of WYD, but also organisational issues, especially transportation solutions. It must be mentioned that such an event as WYD has a huge tourist potential and bears far-reaching consequences and results in the economic dimension, or medial and promotional. It is necessary to draw conclusions and point to the guidelines aiming at improving the shaping of a tourist product from the perspective of the offered transport service. In the context of adjustment to tourists' expectations and facing 
current challenges and needs, a carefully performed analysis is extremely significant, because it is able to facilitate the implementation and improvement of proper codes of conduct during logistic support of events of a similar dimension and importance, taking part in many places all over the world.

\section{References}

Bednarczyk, M., Grabińska, E. (2015). Airport Competitiveness. Models and Assessment Methods. Kraków: Jagiellonian University Press.

Gierczak, B. (2011). The history of tourist transport after the modern industrial revolution. Polish Journal of Sport and Tourism, 275-281.

Gosik, B., Zimon, G. (2014). Usługi transportowe w obsłudze ruchu turystycznego. Zeszyty Naukowe, 843. Problemy Transportu i Logistyki, 28, 37-48.

Grabińska, E., Mierniczak, P. (2015). Methodology of Tourist Mobility Research as an example of research in the field of interdisciplinary science - current state and prospects of development. Contemporary Science Methodology, 61-73.

Gutiereez, A., Miravet, D. (2016). The Determinants of Tourist Use of Public Transport. Sustainability, 8 (9), 1-16.

Jaremen, D., Nawrocka, E. (2012). Rola dostępności komunikacyjnej obszaru recepcji turystycznej w kształtowaniu popytu tursytycznego. Zeszyty Naukowe Uniwersytetu Szczecińskiego. Ekonomiczne Problemy Usług, 83, 401-414.

Kharda0o, J., Seetanah, B. (2007). Transport infrastructure and tourism development. Annals of Tourism Research, 34, 1021-1032.

Kwarciński, T. (2012). Dostępność transportowa jako paradygmat kształtujący wielkość przewozów w publicznym transporcie pasażerskim. Logistyka, 2, 169-173.

Mammadov, R. (2012). The Importance of Transportation in Tourism Sector. 7 the Silk Road International Conference "Challenges and Opportunities of Sustainable Economic Development in Eurasian Countries". Azerbaijan.

Panasiuk, A. (ed.) (2008). Gospodarka turystyczna. Warszawa: Wydawnictwo Naukowe PWN.

Ruch turystyczny w Krakowie. Raport końcowy (2003-2016). Retrieved from: http://www.mot.krakow.pl/media/badanie-ruchuturystycznego/badania.

Sawicki, B. (2012). Rola transport w zagospodarowaniu turystycznym. Logistyka, 3, 1957-1961.

Singleton, A. (2009). The impact of World Youth Day on belief and behaviour, Annual Meeting of the Society for the Scientific Study of Religion Denver. 1-12. CO. Retrieved from: https://resource.acu.edu.au/wyd/UPDATES/SSSR2009/091020_AS_SSSR_2009.pdf.

Seweryn, R. (2007). Preferencje turystów przyjeżdżających do Krakowa w zakresie wyboru środka transport. Zeszyty Naukowe Uniwersytetu Ekonomicznego w Krakowie, 761, 25-44.

Stec, A. (2015). Wieloaspektowe podejście do definicji produktu turystycznego. Modern Management Review, XX (22), 233-248.

Szarata, A., Drabicki, A. (2016). Prognozowanie ruchu drogowego związanego z organizacją Światowych Dni Młodzieży w Krakowie. Prace Naukowe Politechniki Warszawskiej. Transport, 111, 522-530.

Turek M. (red.) (2009). Transport jako składnik produktu turystycznego. Sopot: Europejska Szkoła Hotelarstwa, Turystyki i Przedsiębiorczości - Szkoła Wyższa w Sopocie.

Uczestnicy Swiatowych Dni Młodzieży w Krakowie 2016 (2016). Małopolska Organizacja Turystyczna, Kraków. Retrieded from: http:/l www.mot.krakow.pl/media/rok-2016/badania-uczestnikow-sdm-2016-ocena.pdf.

Westlake, J., Robbins, D. (2005). Transportation. In: C. Cooper, J. Fletcher, A. Fyall, D. Gilbert, S. Wanhill, Tourism: Principles and Practice. 3rd edition. Essex: Pearson Education Limited.

Wilkońska, A., Rotter-Jarzębińska, K. (2013). Zachowania transportowe osób odwiedzająych Kraków w celach turystycznych, ze szczególnym uwzględnieniem przyjazdów w okresie organizacji Euro 2012 w Polsce. Zeszyty Naukowe Małopolskiej Wyższej Szkoły Ekonomicznej w Tarnowie, 1 (22), 173-193.

Cite this article aS: Grabińska, E. (2018). The role and impact of transport services during World Youth Day 2016. European Journal of Service Management, 2 (26), 95-102. DOI: 10.18276/ejsm.2018.26-12. 